\title{
Fetal death and work in pregnancy
}

\author{
A D McDonald, J C McDONALd, B ARMSTRONG, N M CHERRY, R CÔTÉ, \\ J LAVOIE, A D NOLIN, D ROBERT
}

From the Institut de Recherche en Santé et en Sécurité du Travail du Québec, Montréal, Québec H3A 3C2, Canada

ABSTRACT The relation between spontaneous abortion $(n=5010)$, stillbirth without congenital defect $(n=210)$, and working conditions was analysed in 22613 previous pregnancies of 56067 women interviewed, 1982-4, immediately after termination of their most recent (current) pregnancy. The 22613 previous pregnancies were those in which at time of conception the women were employed 30 or more hours a week. Ratios of observed $(\mathrm{O})$ to expected (E) fetal deaths after allowance by logistic regression for seven non-occupational confounding variables were calculated at four stages of pregnancy in 60 occupational groups and six main sectors for women whose work entailed various physical demands, environmental conditions, and exposure to chemicals. The $\mathrm{O} / \mathrm{E}$ ratios for abortion were raised in the sales sector $(1 \cdot 13, \mathrm{p}<0.05)$ and services sector $(1 \cdot 11, \mathrm{p}<0.01)$ and for stillbirth in the sales sector $(1 \cdot 50, \mathrm{p}<0 \cdot 1)$. Substantially increased $\mathrm{O} / \mathrm{E}$ ratios for late but not early abortion were found in operating room nurses $(2.92, \mathrm{p}<0.05)$, radiology technicians $(3.82, \mathrm{p}<0.01)$, and employees in agriculture and horticulture $(2.40, \mathrm{p}<0.05)$; in all categories the $\mathrm{O} / \mathrm{E}$ ratios for stillbirth were also raised but only significantly $(5.55, \mathrm{p}<0.01)$ in the latter group. The $\mathrm{O} / \mathrm{E}$ ratio for stillbirth was also raised in leather manufacture $(3.09, \mathrm{p}<0.01)$. In both individual and grouped analysis (the latter undertaken to minimise the possible effect of recall bias) significantly increased $\mathrm{O} / \mathrm{E}$ ratios for abortion were found in women exposed to various high levels of physical stress, particularly weight lifting, other physical effort, and standing $(\mathrm{p}<0.01)$. Increased ratios for stillbirth at this level of significance $(p<0.01)$ were found for other physical effort and vibration. Noteworthy chemical exposure was identified only in the health, services, and manufacturing sectors; the $\mathrm{O} / \mathrm{E}$ ratio for stillbirth approached two in women exposed to solvents, almost all in manufacturing $(\mathrm{p}<0.01)$. In the latter sector exposure to solvents was also associated with an approximately $20 \%$ increase in abortion ratio at similar probability level.

In a study of occupational factors and outcome of pregnancy 56067 women were interviewed over a two year period (1982-4) after delivery or spontaneous abortion in 11 obstetrical units in Montreal. Questions were asked about recently completed and all previous pregnancies-104649 in all. The study design, data collection, statistical methods, and treatment of confounding variables have been previously outlined. ${ }^{1}$ A systematic analysis of spontaneous abortion, stillbirth, congenital defect, and low birth weight in current and previous pregnancies has been presented in 60 occupational groups in six main sectors. ${ }^{1}$ Women in managerial, health, and clerical sectors had little evidence of excess of any of the four outcomes, in contrast to those in sales, services, and manufacturing sectors. Statistically significant exces-

Accepted 2 March 1987 ses of spontaneous abortion were observed in nursing aides and women in sales occupations and food and beverage service; of stillbirth in agriculture and horticulture, leatherwork, and certain sales occupations; of congenital defects in women in child care, certain service occupations, and the manufacture of metal and electrical goods; and of low birth weight in chambermaids, cleaners, and janitors, and in those engaged in the manufacture of food and drink, metal and electrical goods, and clothing.

A preliminary analysis of spontaneous abortion and certain occupational factors indicated that women whose work entailed heavy lifting, other physical effort, long hours, exposure to noise, and exposure to cold had also significantly increased risk ratios. Nevertheless, when occupational groups were ranked according to work demands, thus avoiding potential bias from prior knowledge of outcome, increased risks were associated consistently only with heavy lifting and other physical effort. ${ }^{2}$ 
The object of the present report is to explore in detail the relation of physical requirements of work, environmental conditions, and chemical exposures to embryonic and fetal death at various stages in pregnancy. In current (recently completed) pregnancies spontaneous abortions were limited by the study design to those admitted to hospital; they were therefore deficient in early abortions for which admission was unnecessary. Women who had just had a stillborn child also proved difficult to interview because they were both distressed and in hospital for only a short time. The present analysis has therefore been restricted to previous pregnancies in which ascertainment of recognised spontaneous abortions was probably close to complete and information about environmental factors at work less liable to subject or observer bias than after the emotional trauma of abortion or stillbirth. ${ }^{2}$

\section{Methods}

\section{ST U D Y G R O U P}

The occurrence of spontaneous abortion at less than 28 weeks gestation was studied in single pregnancies of women employed 30 or more hours a week at time of conception. The term abortion in this paper is restricted to those believed to be spontaneous; care was taken to exclude induced abortions (permitted in Quebec). Abortions were studied at three periods of gestation: (1) early: less than 10 weeks, (2) mid: 10 and less than 16 weeks, and (3) late: 16 and less than 28 weeks. Fetuses of 20 or more weeks gestation with a congenital abnormality were excluded from this analysis and will be dealt with later in a comprehensive analysis of defects. There were 22613 previous pregnancies in which women were employed 30 or more hours a week when they became pregnant. Overall, $5010(22 \cdot 2 \%)$ ended in abortion before the 28 th week: $1867(8.3 \%)$ at less than 10 weeks, $2512(11 \cdot 1 \%)$ from 10 to 15 weeks, and $631(2.8 \%)$ after the 15 th week. For the analyses in each period, pregnancies that had terminated earlier were excluded from the denominator. Stillbirths after the 27th week without observed defect were studied in single pregnancies of women employed 30 or more hours a week for two weeks or more at any time in pregnancy. In 18511 such pregnancies there were $210(1 \cdot 1 \%)$ stillbirths without congenital defect.

OCCUPATION AND WORK

RE Q U I R E M E N T S

Occupations were coded from questions similar to those used in the Canadian Census. Each job was allocated a four digit occupational code and a two digit industrial code according to the Standard Occupational and Industrial Classifications of Statis- tics Canada (1980). ${ }^{34}$ Detailed information about all work in pregnancy was obtained in a standard manner from the women at interview. ${ }^{1}$ The work requirements and physical environmental conditions were recorded at several levels of intensity. The use of visual display units was included in this record; as preliminary reports have been made on this subject ${ }^{56}$ it will not be considered again until the final analyses have been made.

CHEMICAL EXPOSURES

All coded jobs were reviewed without knowledge of outcome by one of us ( $\mathrm{JL}$, an industrial hygienist) and an estimate was made of chemical exposures by type and level. This was done using (1) information obtained from two case-referent field studies of congenital defects, one in current pregnancies ${ }^{7}$ and the other in previous pregnancies (unpublished); (2) data from visits and measurements made for occupational surveillance by local health departments; (3) estimates made for occupations and industries in the Montreal region for a study of occupational exposure and cancer $^{8}$; and (4) other texts and research reports. Exposure to each chemical substance was classified in three levels: (1) reaching an estimated maximum of less than $30 \%$ of the threshold limit value (TLV), (2) reaching about $30 \%$ of the TLV, and (3) probably reaching the TLV. In the systematic review when five pregnancies with the same occupational and industrial code were found to have the same chemical exposures, these were accepted as the "chemical profile." If within a single six digit code there were different exposures the six digit category was subdivided into homogeneous exposure groups and reviews were continued until five pregnancies were found with similar exposures. Thirty six from a total of 324 occupational categories with some chemical exposure were subdivided because they were not homogeneous. Only exposures at levels (2) and (3) were included in the analysis. These levels were achieved in 127 occupational categories. Chemical exposures were classified in four groups: (1) organic solvents, (2) pesticides (including bactericides, fungicides, and herbicides), (3) anaesthetic gases, and (4) other biologically active chemicals. Exposure to antineoplastic drugs was ascertained from the response of doctors and nurses to a question on whether they had administered such drugs during the four weeks after their first missed menstrual period.

ST A T IS T I C A L A NA L Y SES

Individual-Risk of fetal death in a specific group relative to that among all working women was estimated as a ratio of observed $(O)$ to expected $(E)$ numbers. The statistical methods used to calculate expected numbers, having accounted for confounding 
variables, to carry out tests of significance, and to estimate confidence intervals have been described in previous reports. ${ }^{12}$ In the current analyses expected numbers were calculated for early, mid, and late spontaneous abortions separately, accounting for age, gravidity, history of previous abortion, ethnic group, educational level, and also smoking habit and alcohol consumption (the latter two at the start of pregnancy). Ratios of observed to expected fetal deaths were calculated for 60 occupations in six main occupational sectors. The 60 occupations and six sectors were selected from the Standard Occupational and Industrial Classifications of Statistics Canada, ${ }^{34}$ bringing together jobs similar in work requirements and conditions. For work requirements, environmental conditions, and chemical exposures $\mathrm{O} / \mathrm{E}$ ratios were calculated in subgroups within each of the six main sectors. Underlying patterns of $\mathrm{O} / \mathrm{E}$ ratios were investigated by Poisson regression methods using the GLIM Computer Package. ${ }^{9}$

Grouped-Because of the possibility of interviewersubject bias in retrospectively collected data, a second method of estimating risk associated with work requirements and conditions was also used. In this method the proportion of all women reporting a par- ticular work factor was calculated for each of the $\mathbf{6 0}$ occupational groups. Relative risks associated with the work factor were then estimated from the (Poisson) regression of $\mathrm{O} / \mathrm{E}$ ratios for each occupational group on the proportion reporting that factor in the group. This method was essentially as described in the context of ecological study analysis. ${ }^{10}$ Because the proportion of women in an occupational group who reported a work factor depended predominantly on the responses from women who had liveborn children, these estimates of risk should be minimally affected by response bias. This type of analysis was not thought necessary for the chemical exposures which were estimated objectively.

\section{Results}

After allowance for the confounding variables the number of abortions and stillbirths observed was close to that expected in four occupational sectorsmanagerial, health, clerical, and manufacturing (table 1). For women employed in sales occupations there were raised ratios $(\mathrm{O} / \mathrm{E})$ for abortions $(1 \cdot 13, \mathrm{p}<0.05)$ and for stillbirths $(1 \cdot 50, p<0 \cdot 1)$ and in service occupations an overall excess of abortions $(\mathrm{O} / \mathrm{E} 1 \cdot 10$,

Table 1 Ratios of observed $(O)$ to expected $(E)$ abortions and stillbirths by occupational sector

\begin{tabular}{|c|c|c|c|c|c|c|c|}
\hline & \multicolumn{4}{|l|}{ Abortions } & \multicolumn{3}{|l|}{ Stillbirths } \\
\hline & $\begin{array}{l}\text { Total } \\
\text { pregnancies }\end{array}$ & Period & $O$ & $O / E$ & $\begin{array}{l}\text { Total } \\
\text { pregnancies }\end{array}$ & $O$ & $O / E$ \\
\hline 1 Managerial & 3831 & $\begin{array}{l}1 \\
2 \\
3\end{array}$ & $\begin{array}{r}293 \\
447 \\
98\end{array}$ & $\begin{array}{llll}0.89 & & & \\
1.02 & & & \\
0.95 & & & \\
\text { Total } & 838 & 0.96\end{array}$ & 3122 & 29 & 0.87 \\
\hline 2 Health & 2726 & $\begin{array}{l}1 \\
2 \\
3\end{array}$ & $\begin{array}{r}252 \\
297 \\
70\end{array}$ & $\begin{array}{llll}1.13^{* *} & & & \\
0.98 & & & \\
0.96 & & & \\
\text { Total } & 619 & 1.04\end{array}$ & 2187 & 23 & 0.97 \\
\hline 3 Clerical & 9527 & $\begin{array}{l}1 \\
2 \\
3\end{array}$ & $\begin{array}{l}776 \\
969 \\
235\end{array}$ & $\begin{array}{lll}1.02 & & \\
0.95 & & \\
0.92 & & \\
\text { Total } & 1980 & 0.97\end{array}$ & 7875 & 81 & 0.92 \\
\hline 4 Sales & 1070 & $\begin{array}{l}1 \\
2 \\
3\end{array}$ & $\begin{array}{r}96 \\
149 \\
31\end{array}$ & $\begin{array}{l}1.04 \\
1 \cdot 22^{* * *} \\
1.04 \\
\text { Total } 276 \quad 1 \cdot 13^{* *}\end{array}$ & 840 & 15 & $1.50^{*}$ \\
\hline 5 Services & 1705 & $\begin{array}{l}1 \\
2 \\
3\end{array}$ & $\begin{array}{r}162 \\
234 \\
61\end{array}$ & $\begin{array}{l}1 \cdot 05 \\
1 \cdot 13^{* *} \\
1 \cdot 16 \\
\text { Total } 457 \quad 1 \cdot 10^{* * *}\end{array}$ & 1343 & 20 & $1 \cdot 16$ \\
\hline 6 Manufacturing & 3751 & $\begin{array}{l}1 \\
2 \\
3\end{array}$ & $\begin{array}{l}288 \\
415 \\
136\end{array}$ & $\begin{array}{lll}0.94 & & \\
0.98 & & \\
1 \cdot 16^{* *} & & \\
\text { Total } 839 & 0.99\end{array}$ & 3142 & 42 & $1 \cdot 13$ \\
\hline Total & 22613 & $\begin{array}{l}1 \\
2 \\
3\end{array}$ & $\begin{array}{r}1867 \\
2512 \\
631\end{array}$ & $\begin{array}{lll}1.00 & & \\
1.00 & & \\
1.00 & & \\
\text { Total } & 5010 \quad 1.00\end{array}$ & 18511 & 210 & 1.00 \\
\hline
\end{tabular}

Period: 1 = less than 10 weeks (early),

$2=10$ and less than 16 weeks (mid)

$3=16$ and less than 28 week
${ }^{*} p<0.1 ;{ }^{* *} p<0.05 ;{ }^{* * *} p<0.01$. 
Table 2 Ratios of observed $(O)$ to expected (E) abortions by duration of gestation and stillbirths

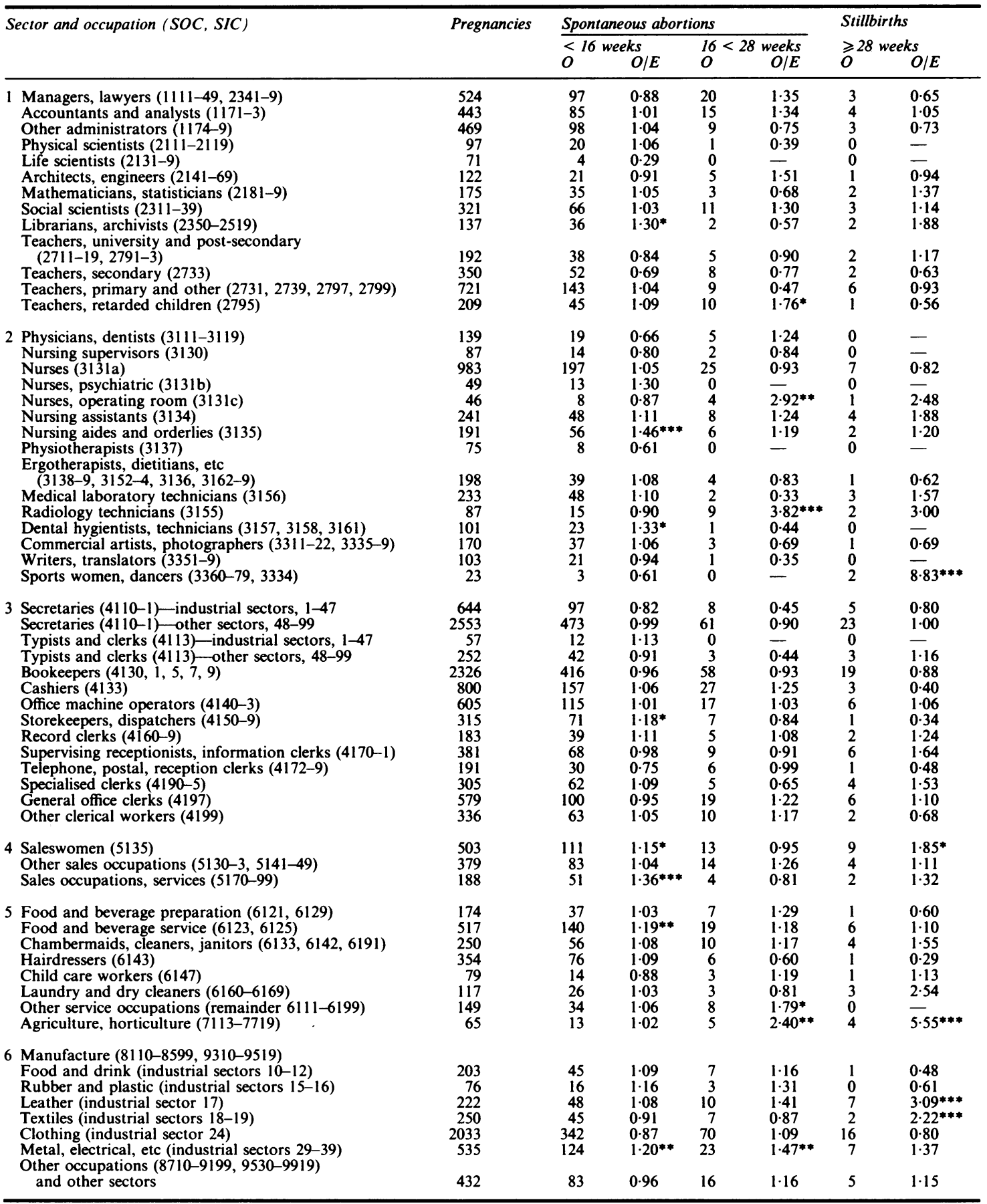

${ }^{*} \mathrm{p}<0.1 ;{ }^{* *} \mathrm{p}<0.05 ;{ }^{* * *} \mathrm{p}<0.01$ 


\begin{tabular}{|c|c|c|c|c|c|c|}
\hline & \multicolumn{6}{|c|}{ Occupational sector } \\
\hline & \multicolumn{2}{|c|}{$\begin{array}{l}\text { Managerial } \\
\text { Mand }\end{array}$} & \multicolumn{2}{|c|}{$\underset{\text { Health }}{2}$} & \multicolumn{2}{|c|}{$\begin{array}{l}3 \\
\text { Clerical }\end{array}$} \\
\hline & $O$ & $O / E$ & $O$ & $O / E$ & $O$ & $O / E$ \\
\hline $\begin{array}{l}\text { Work requirements: } \\
\text { Lifting heavy weights ( } \geqslant 15 \text { times a day) } \\
\text { Other physical effort } \\
\text { Standing ( } \geqslant 8 \text { hours a day) } \\
\text { Long working hours ( } \geqslant 46 \text { hours a week) } \\
\text { Changing shift }\end{array}$ & $\begin{array}{l}15 \\
54 \\
18 \\
36 \\
11\end{array}$ & $\begin{array}{l}1 \cdot 28 \\
1.41 * * * \\
0.86 \\
0.97 \\
1.08\end{array}$ & $\begin{array}{r}72 \\
120 \\
76 \\
46 \\
118\end{array}$ & $\begin{array}{l}1 \cdot 24^{* *} \\
1 \cdot 26^{* * *} \\
1 \cdot 12 \\
1 \cdot 35^{* *} \\
1 \cdot 22^{* * *}\end{array}$ & $\begin{array}{r}56 \\
76 \\
105 \\
44 \\
26\end{array}$ & $\begin{array}{l}1 \cdot 65^{* * *} \\
1 \cdot 52^{* * *} \\
1 \cdot 37^{* * *} \\
1 \cdot 17 \\
1 \cdot 23\end{array}$ \\
\hline $\begin{array}{l}\text { Environmental conditions: } \\
\text { Noise (great) } \\
\text { Vibration (great) } \\
\text { Too cold } \\
\text { Too hot }\end{array}$ & $\begin{array}{r}128 \\
8 \\
36 \\
112\end{array}$ & $\begin{array}{l}1.07 \\
0.82 \\
1.26^{*} \\
0.92\end{array}$ & $\begin{array}{r}78 \\
7 \\
17 \\
117\end{array}$ & $\begin{array}{l}1.05 \\
1.80^{*} \\
1.12 \\
0.95\end{array}$ & $\begin{array}{r}320 \\
25 \\
174 \\
223\end{array}$ & $\begin{array}{l}1 \cdot 13^{* * *} \\
1 \cdot 15 \\
1 \cdot 15^{* *} \\
0.91\end{array}$ \\
\hline Total & 838 & 0.96 & 619 & 1.04 & 1980 & 0.97 \\
\hline
\end{tabular}

${ }^{*} \mathrm{p}<0 \cdot 1 ;{ }^{* *} \mathrm{p}<0.05 ;{ }^{* * *} \mathrm{p}<0.01$

$\mathrm{p}<0.01$ ). Homogeneity of ratios by sector was rejected for abortion $(p<0.01)$ but not for stillbirth $(\mathrm{p}>0 \cdot 20)$. Despite some apparent differences in $\mathrm{O} / \mathrm{E}$ ratios between abortions in the three periods, formal tests for heterogeneity showed no evidence of more variation than could be accounted for by chance.

In table $2 \mathrm{O} / \mathrm{E}$ ratios are shown for early and mid abortions combined-that is, less than 16 weeks gestation-for late abortions (16 to 27 weeks) and for stillbirths $(\geqslant 28$ weeks). For all abortions $(<28$ weeks) there was significant heterogeneity $(p<0.01)$ between the 60 ratios; $\mathrm{O} / \mathrm{E}$ ratios were increased for nursing aides and orderlies $(1.43, p<0.01)$, food and beverage servers $(1 \cdot 18, p<0.01)$, and workers in factories making metal and electrical and certain other products $(1.23, \mathrm{p}<0.01)$. For saleswomen $(\mathrm{CCDO}$ 5135 ) there was a small increase in the $\mathrm{O} / \mathrm{E}$ ratio for all abortions $(1 \cdot 12, p<0 \cdot 1)$. Librarians had an increased ratio for abortion at less than 16 weeks $(1.30, \mathrm{p}<0.10)$ as had dental hygienists $(1.33$, $\mathrm{p}<0 \cdot 1)$ and women who sold services, such as insurance etc $(1.36, p<0.01)$. Substantially increased ratios $(\mathrm{O} / \mathrm{E})$ for late but not early abortions were found in operating room nurses $(2.92, p<0.05)$, radiology technicians $(3.82, p<0.01)$, and agricultural and horticultural workers $(2.40, p<0.05)$. Raised $\mathrm{O} / \mathrm{E}$ ratios for stillbirths were also found in operating room nurses $(2 \cdot 48, p=0 \cdot 40)$, radiology technicians $(3.00, p=0.40)$, and in agricultural and horticultural workers $(5.55, \mathrm{p}<0.01)$; the first two were based on few cases and so lacked statistical significance. A raised $\mathrm{O} / \mathrm{E}$ ratio for stillbirth was found in leather manufacture $(3.09, \mathrm{p}<0.01)$.

Table 3 shows that $\mathrm{O} / \mathrm{E}$ ratios for all abortions ( $<28$ weeks) were increased for the following work requirements and conditions: lifting heavy weights more than 15 times a day $(1.45, \mathrm{p}<0.01)$, other physical effort $(1.37, p<0.01)$, standing more than eight hours a day $(1 \cdot 18, p<0.01)$, working 46 or more hours a week $(1 \cdot 19, \mathrm{p}<0.01)$, changing shift work $(1.25, p<0.01)$, and in women who reported exposure to noise $(1 \cdot 18, \mathrm{p}<0 \cdot 01)$, cold $(1 \cdot 19$, $\mathrm{p}<0.01)$, and vibration $(1.13, \mathrm{p}<0.05)$. Poisson regression analyses showed that for each of the factors reported in the table, patterns of excess risk were consistent between sectors-that is, variations in $\mathrm{O} / \mathrm{E}$ ratios between sectors were no more than could be accounted for by chance $(p>0 \cdot 10)$. Furthermore, the total $\mathrm{O} / \mathrm{E}$ ratios were changed negligibly after allowing for differences between sectors. For heavy lifting, physical effort, long hours of work, exposure to noise, and exposure to vibration, the ratio $(\mathrm{O} / \mathrm{E})$ increased significantly $(\mathrm{p}<0.01)$ with increasing grade of the factor (table 4). For standing, the trend was of low statistical significance $(p<0 \cdot 10)$.

Risk ratios according to work requirements and conditions were also calculated separately for early, mid, and late abortions (table 5). For all factors except changing shift work and excessive heat the ratios were highest for late abortions, but the differences between periods approached statistical significance only for noise $(p<0 \cdot 10)$ and cold $(p<0 \cdot 10)$. Ratios $(O / E)$ for stillbirth (also shown in table 5) were raised with physical effort $(1 \cdot 87$, $\mathrm{p}<0.01)$, vibration $(2.81, \mathrm{p}<0.01)$, and with standing $(1.46, p<0.05)$.

These work conditions and requirements were moderately correlated with each other, therefore multivariate analyses were carried out to determine possible confounding of one factor by another. In this analysis the six factors showing an $\mathrm{O} / \mathrm{E}$ ratio in excess of 1.15-that is, all except noise, vibration, and 


\begin{tabular}{|c|c|c|c|c|c|c|c|}
\hline \multicolumn{2}{|c|}{4} & \multicolumn{2}{|c|}{$\begin{array}{l}5 \\
\text { Services }\end{array}$} & \multicolumn{2}{|c|}{$\stackrel{6}{\text { Manufacturing }}$} & \multicolumn{2}{|l|}{ Total } \\
\hline$O$ & $O / E$ & $O$ & $O / E$ & $O$ & $O / E$ & $O$ & $O / E$ \\
\hline $\begin{array}{r}30 \\
25 \\
87 \\
51 \\
2\end{array}$ & $\begin{array}{l}1 \cdot 70^{* * *} \\
1 \cdot 33^{*} \\
1.27^{* * *} \\
1 \cdot 16 \\
0.92\end{array}$ & $\begin{array}{r}66 \\
90 \\
232 \\
94 \\
52\end{array}$ & $\begin{array}{l}1 \cdot 50^{* * *} \\
1 \cdot 40^{* * *} \\
1 \cdot 23^{* * *} \\
1 \cdot 19^{* *} \\
1 \cdot 42^{* * *}\end{array}$ & $\begin{array}{r}119 \\
110 \\
215 \\
35 \\
15\end{array}$ & $\begin{array}{l}1.47^{* * *} \\
1.35^{* * *} \\
1.07 \\
1.41^{* *} \\
1.24\end{array}$ & $\begin{array}{l}358 \\
475 \\
733 \\
306 \\
224\end{array}$ & $\begin{array}{l}1 \cdot 45^{* * *} \\
1 \cdot 37^{* * *} \\
1 \cdot 18^{* * *} \\
1 \cdot 19^{* * *} \\
1 \cdot 25^{* * *}\end{array}$ \\
\hline $\begin{array}{r}36 \\
2 \\
27 \\
29\end{array}$ & $\begin{array}{l}1.41^{* *} \\
0.90 \\
1.28^{*} \\
1.07\end{array}$ & $\begin{array}{r}138 \\
28 \\
19 \\
119\end{array}$ & $\begin{array}{l}1 \cdot 25^{* * * *} \\
1 \cdot 79 * * * \\
1.48 * * \\
1.06\end{array}$ & $\begin{array}{r}447 \\
79 \\
54 \\
242\end{array}$ & $\begin{array}{l}1.00 \\
1.01 \\
1.20 * \\
1.00\end{array}$ & $\begin{array}{r}1147 \\
149 \\
327 \\
843\end{array}$ & $\begin{array}{l}1.08^{* * *} \\
1 \cdot 13^{* *} \\
1 \cdot 19^{* *} \\
0.97\end{array}$ \\
\hline 276 & $1 \cdot 13$ & 457 & $1 \cdot 10$ & 839 & 0.99 & 5010 & 1.00 \\
\hline
\end{tabular}

heat-were entered simultaneously into a Poisson regression of ratios for groups comprising all possible combinations of the six factors (table 6). Estimates of relative risk of each factor adjusting in this way for the other five were slightly lower than the unadjusted ratios but remained statistically significant (lifting: $R R=1.32, p<0.01 ;$ physical effort: $R R=1.26$, $p<0.01$, standing $R R=1.09, p<0.05$; long hours: $\mathrm{RR}=1 \cdot 13, \quad \mathrm{p}<0.05 ; \quad$ shift work: $\quad \mathrm{RR}=1 \cdot 17$, $\mathrm{p}<0.05$; cold: $\mathrm{RR}=1.20, \mathrm{p}<0.01$ ).

Except for noise and vibration the grouped analysis gave rather higher estimates of relative risk than the $\mathrm{O} / \mathrm{E}$ ratios from the individual analysis. Confidence intervals around the former estimates, however, were wide and $p$ values generally higher than those in the individual analysis.
The frequency with which the four types of chemical exposure occurred in four of the six main occupational sectors is shown in table 7 , both total and only. No chemical exposure at levels 2 or 3 was identified in the profiles of women in the clerical and sales sectors. Table 8 shows that of the four groups of chemicals, only solvent exposure with or without other chemical exposure was associated with an increased $\mathrm{O} / \mathrm{E}$ ratio for stillbirths; this was seen in manufacturing $(\mathrm{O} / \mathrm{E} 2.76, \mathrm{p}<0.01)$ but not other sectors. Since leather manufacture was accompanied by an increase in $\mathrm{O} / \mathrm{E}$ ratio for stillbirths ${ }^{11}{ }^{12}$ solvent exposure was analysed in this industry. The $\mathrm{O} / \mathrm{E}$ ratio for stillbirths in solvent exposed pregnancies in leatherworkers was $3.12(p<0.01)$ and in the remainder of the manufacturing sector 2.43

Table 4 Ratios of observed $(O)$ to expected $(E)$ abortions by grade of certain work requirements and conditions

\begin{tabular}{|c|c|c|c|c|c|}
\hline $\begin{array}{l}\text { Lifting weights } \\
O / E \\
\text { (O) }\end{array}$ & $\begin{array}{c}\text { None or light } \\
0.92 \\
(3393)\end{array}$ & $\begin{array}{c}\text { Medium } \\
1 \cdot 11 \\
(665)\end{array}$ & $\begin{array}{c}\text { Heavy } \\
<15 \text { times } \\
1 \cdot 28 \\
(581)\end{array}$ & $\begin{array}{c}\text { Heavy } \\
\geqslant 15 \text { times } \\
1.45 \\
(358)\end{array}$ & $\begin{array}{l}p \text { for trend } \\
<0.01\end{array}$ \\
\hline $\begin{array}{l}\text { Physical effort } \\
O / E \\
\text { (O) }\end{array}$ & $\begin{array}{l}\text { None } \\
0.95 \\
(3964)\end{array}$ & $\begin{array}{c}\text { Moderate } \\
1 \cdot 14 \\
(538)\end{array}$ & $\begin{array}{c}\text { Great } \\
1 \cdot 37 \\
(475)\end{array}$ & & $<0.01$ \\
\hline $\begin{array}{l}\text { Standing } \\
O / E \\
(\mathrm{O})\end{array}$ & $\begin{array}{c}<3 \text { hours } \\
0.93 \\
(2019)\end{array}$ & $\begin{array}{l}3-7 \text { hours } \\
1 \cdot 01 \\
(2200)\end{array}$ & $\begin{array}{l}>8 \text { hours } \\
1 \cdot 18 \\
(733)\end{array}$ & & $<0.1$ \\
\hline $\begin{array}{l}\text { Working hours/week } \\
O / E \\
\text { (O) }\end{array}$ & $\begin{array}{c}30-35 \\
0.99 \\
(1776)\end{array}$ & $\begin{array}{c}36-40 \\
0.98 \\
(2700)\end{array}$ & $\begin{array}{c}41-45 \\
1.07 \\
(228)\end{array}$ & $\begin{array}{l}\geqslant 46 \\
1 \cdot 19 \\
(306)\end{array}$ & $<0.01$ \\
\hline $\begin{array}{l}\text { Noise } \\
O / E \\
\text { (O) }\end{array}$ & $\begin{array}{l}\text { None } \\
0.96 \\
(2116)\end{array}$ & $\begin{array}{c}\text { Moderate } \\
0.99 \\
(1468)\end{array}$ & $\begin{array}{l}\text { Great } \\
1.08 \\
(1147)\end{array}$ & & $<0.01$ \\
\hline $\begin{array}{l}\text { Vibration } \\
O / E \\
\text { (O) }\end{array}$ & $\begin{array}{l}\text { None } \\
0.99 \\
(4447)\end{array}$ & $\begin{array}{c}\text { Moderate } \\
1 \cdot 10 \\
(358)\end{array}$ & $\begin{array}{c}\text { Great } \\
1 \cdot 13 \\
(149)\end{array}$ & & $<0.01$ \\
\hline
\end{tabular}


Table 5 Ratios of observed $(O)$ to expected $(E)$ abortions by period according to work requirements and conditions

\begin{tabular}{|c|c|c|c|c|c|c|}
\hline & & \multicolumn{3}{|l|}{ Abortions } & \multirow[b]{2}{*}{$\begin{array}{l}\text { Stillbirths } \\
(\geqslant 28 w k s)\end{array}$} & \multirow{2}{*}{$\begin{array}{l}\text { Difference in } O / E \\
\text { ratios between } \\
\text { time periods } \\
p\end{array}$} \\
\hline & & $\begin{array}{l}\text { (1) Early } \\
(<10 \text { wks })\end{array}$ & $\begin{array}{l}\text { (2) Mid } \\
(10<16 w k s)\end{array}$ & $\begin{array}{l}\text { (3) Late } \\
\text { (16<28wks) }\end{array}$ & & \\
\hline $\begin{array}{l}\text { Work requirements: } \\
\text { Lifting heavy weights } \\
\text { ( } \geqslant 15 \text { times daily) } \\
\text { Other physical effort } \\
\text { Standing } \\
\text { ( } \geqslant 8 \text { hours daily) } \\
\text { Long hours } \\
\text { ( } \geqslant 46 \text { hours/week) } \\
\text { Changing shift }\end{array}$ & $\begin{array}{l}\mathrm{O} \\
O / E \\
\mathrm{O} \\
O / E \\
\mathrm{O} \\
O / E \\
\mathrm{O} \\
O / E \\
\mathrm{O} \\
O / E\end{array}$ & $\begin{array}{l}123 \\
l \cdot 33^{* *} \\
174 \\
l \cdot 33^{* *} \\
258 \\
I \cdot 12^{* *} \\
120 \\
I \cdot 20^{* *} \\
90 \\
l \cdot 29^{* * *}\end{array}$ & $\begin{array}{l}188 \\
1 \cdot 51^{* * *} \\
235 \\
1 \cdot 35^{* * *} \\
377 \\
1 \cdot 20^{* * *} \\
141 \\
1 \cdot 13^{*} \\
112 \\
1 \cdot 26^{* * *}\end{array}$ & $\begin{array}{l}47 \\
1 \cdot 61^{* * *} \\
66 \\
1 \cdot 54^{* * *} \\
98 \\
1 \cdot 23^{* * *} \\
45 \\
1 \cdot 44^{* * *} \\
22 \\
1 \cdot 08\end{array}$ & $\begin{array}{l}10 \\
1 \cdot 13 \\
25 \\
1 \cdot 87^{* * *} \\
39 \\
1 \cdot 46^{* *} \\
9 \\
0 \cdot 89 \\
4 \\
0 \cdot 61\end{array}$ & $\begin{array}{l}>0.1 \\
>0.1 \\
>0.1 \\
>0.1 \\
>0.1\end{array}$ \\
\hline $\begin{array}{l}\text { Environmental condition } \\
\text { Noise (great) } \\
\text { Vibration (great) } \\
\text { Too cold } \\
\text { Too hot }\end{array}$ & $\begin{array}{l}\mathrm{O} \\
O / E \\
\mathrm{O} \\
O / E \\
\mathrm{O} \\
O / E \\
\mathrm{O} \\
O / E\end{array}$ & $\begin{array}{c}389 \\
1.00 \\
53 \\
1.09 \\
111 \\
1.09 \\
283 \\
0.88\end{array}$ & $\begin{array}{l}595 \\
l \cdot 12^{* * *} \\
73 \\
l \cdot 12 \\
161 \\
1 \cdot 16^{* *} \\
453 \\
1 \cdot 03\end{array}$ & $\begin{array}{l}163 \\
l \cdot 19^{* *} \\
23 \\
1 \cdot 35^{*} \\
55 \\
1 \cdot 62^{* * *} \\
107 \\
0.96\end{array}$ & $\begin{array}{l}47 \\
1 \cdot 08 \\
15 \\
2 \cdot 81^{* * *} \\
14 \\
1 \cdot 24 \\
46 \\
1 \cdot 25^{*}\end{array}$ & $\begin{array}{l}<0.1 \\
>0.1 \\
<0.1 \\
>0.1\end{array}$ \\
\hline
\end{tabular}

${ }^{*} \mathrm{p}=<0.1 ;{ }^{* *} \mathrm{p}=<0.05 ;{ }^{* * *} \mathrm{p}=<0.01$.

$(p<0.05)$. In the managerial, health, or services sectors there was no indication that solvent exposure was associated with risk of fetal death.

Exposure to anaesthetic gases occurred only in the health sector and rarely without exposure to other chemicals. For abortions, the $\mathrm{O} / \mathrm{E}$ ratio was 1.07 $(\mathrm{O}=17)$. Health personnel were also exposed to the group of pesticides, bactericides, etc, for which the $\mathrm{O} / \mathrm{E}$ ratio was $0.97(\mathrm{O}=39)$. Sixty three nurses or doctors stated that they had administered antineoplastic drugs in the four weeks after their first missed menstrual period; 13 had had abortions $(\mathrm{O} / \mathrm{E}=0.97)$ and none had had a stillbirth $(\mathrm{E}=0 \cdot 48)$.

\section{Discussion}

Many circumstances affect the recognition and reporting of spontaneous abortions. ${ }^{13}$ Those that reach hospital are inevitably selected; early abortions are poorly represented and education and occupation affect the probability of hospital treatment. ${ }^{14}$ Information on previous pregnancies has therefore been suggested as a more satisfactory source of data for epidemiological studies than that on cases in hospital. ${ }^{13}$ Early abortions are less well recalled than those occurring later but, under favourable circumstances, over $90 \%$ of abortions at 13 or more weeks were remembered even after a long interval. ${ }^{15}$

With information obtained retrospectively the possibility of response bias must be considered, especially for subjective items. It is unlikely that questions on which the occupational classification was based were subject to bias and the replies were coded without knowledge of outcome. Certain information, such as on hours of work and type of shift, was relatively objective. Chemical exposures were assessed from the occupational history without knowledge of outcome. On the other hand, the response to questions on other aspects of work in pregnancy could have been coloured by events, especially if emotionally traumatic as with abortion or stillbirth.

There have been a few occupational studies of fetal death with which to compare our findings. In Finland the risk of abortion was also low in administrative and office work but raised in manufacturing, construction, and agriculture. ${ }^{16}$ In the United States the risk of stillbirth was high in manufacturing relative to other occupations. ${ }^{17}$ We did not find this, but in a group of industrial workers, mainly metal and electrical, there was an excess of abortion. Metal work

Table 6 Relative risks of abortion by work requirements and environmental conditions by grouped analysis

\begin{tabular}{|c|c|c|c|}
\hline & $\begin{array}{l}\text { Relative } \\
\text { risk }\end{array}$ & $\begin{array}{l}90 \% \text { Confidence } \\
\text { intervals }\end{array}$ & $p$ \\
\hline \multicolumn{4}{|l|}{ Work requirements: } \\
\hline \multicolumn{4}{|l|}{ Heavy weight lifting } \\
\hline$(\geqslant 15$ times daily) & 2.00 & $1 \cdot 5-2 \cdot 5$ & $<0.01$ \\
\hline Other physical effort & 1.87 & $1 \cdot 4-2 \cdot 3$ & $<0.01$ \\
\hline \multicolumn{4}{|l|}{ Standing } \\
\hline \multicolumn{4}{|l|}{ Long hours } \\
\hline$(\geqslant 46$ hours weekly) & $1 \cdot 33$ & $0.9-1 \cdot 8$ & 0.08 \\
\hline Changing shift & 1.45 & $1.0-1.9$ & 0.04 \\
\hline \multicolumn{4}{|l|}{ Environmental conditions: } \\
\hline Noise & 1.06 & $0 \cdot 9-1 \cdot 3$ & 0.4 \\
\hline Vibration & $1 \cdot 14$ & $0 \cdot 3-2 \cdot 1$ & 0.4 \\
\hline Cold & 1.55 & $0 \cdot 7-2 \cdot 5$ & 0.14 \\
\hline
\end{tabular}


Table 7 Frequency of chemical exposures by occupational sector*

\begin{tabular}{|c|c|c|c|c|c|c|c|c|c|c|}
\hline & \multicolumn{2}{|c|}{ Managerial } & \multicolumn{2}{|c|}{ Health } & \multicolumn{2}{|c|}{ Service } & \multicolumn{2}{|c|}{ Manufacturing } & \multicolumn{2}{|l|}{ Total } \\
\hline & No & $\%$ & No & $\%$ & No & $\%$ & No & $\%$ & No & $\%$ \\
\hline $\begin{array}{l}\text { Solvents: } \\
\text { All* } \\
\text { Alone }\end{array}$ & $\begin{array}{r}192 \\
43\end{array}$ & $\begin{array}{l}5 \cdot 0 \\
1 \cdot 1\end{array}$ & $\begin{array}{l}215 \\
169\end{array}$ & $\begin{array}{l}7.9 \\
6.2\end{array}$ & $\begin{array}{l}44 \\
43\end{array}$ & $\begin{array}{l}2.6 \\
2.5\end{array}$ & $\begin{array}{l}504 \\
445\end{array}$ & $\begin{array}{l}13.4 \\
11.9\end{array}$ & $\begin{array}{l}955 \\
700\end{array}$ & $\begin{array}{l}4 \cdot 2 \\
3 \cdot 1\end{array}$ \\
\hline $\begin{array}{l}\text { Pesticides: } † \\
\text { All* } \\
\text { Alone }\end{array}$ & $\begin{array}{l}\mathbf{0} \\
\mathbf{0}\end{array}$ & - & $\begin{array}{r}179 \\
70\end{array}$ & $\begin{array}{l}6 \cdot 6 \\
2 \cdot 6\end{array}$ & $\begin{array}{l}24 \\
24\end{array}$ & $\begin{array}{l}1.4 \\
1.4\end{array}$ & $\begin{array}{l}0 \\
0\end{array}$ & - & $\begin{array}{r}203 \\
94\end{array}$ & $\begin{array}{l}0.9 \\
0.4\end{array}$ \\
\hline $\begin{array}{l}\text { Anaesthetic gases: } \\
\text { All* } \\
\text { Alone }\end{array}$ & $\begin{array}{l}0 \\
0\end{array}$ & - & $\begin{array}{r}70 \\
4\end{array}$ & $\begin{array}{l}2 \cdot 6 \\
0 \cdot 1\end{array}$ & $\begin{array}{l}\mathbf{0} \\
0\end{array}$ & - & $\begin{array}{l}0 \\
0\end{array}$ & - & $\begin{array}{r}70 \\
4\end{array}$ & $\begin{array}{l}0.3 \\
0.0\end{array}$ \\
\hline $\begin{array}{l}\text { Other chemicals: } \\
\text { All* } \\
\text { Alone }\end{array}$ & $\begin{array}{r}153 \\
4\end{array}$ & $\begin{array}{l}4 \cdot 0 \\
0 \cdot 1\end{array}$ & $\begin{array}{r}123 \\
88\end{array}$ & $\begin{array}{l}4 \cdot 5 \\
3 \cdot 2\end{array}$ & $\begin{array}{l}448 \\
448\end{array}$ & $\begin{array}{l}26 \cdot 2 \\
26 \cdot 2\end{array}$ & $\begin{array}{l}291 \\
232\end{array}$ & $\begin{array}{l}7.8 \\
6.2\end{array}$ & $\begin{array}{r}1015 \\
772\end{array}$ & $\begin{array}{l}4.5 \\
3.4\end{array}$ \\
\hline Total pregnancies & 3831 & & 2726 & & 1705 & & 3751 & & $22613 \ddagger$ & \\
\hline
\end{tabular}

*With or without other chemical exposures.

tIncluding bactericides, fungicides, and herbicides.

$\ddagger$ Clerical and sales sectors omitted but included in total.

was one of the occupations identified as at increased risk in Finland ${ }^{18}$ and also in the State of Washington, USA. ${ }^{19}$

Continuous heavy lifting was associated with abortion in a study of pharmaceutical industry employees in Finland, ${ }^{20}$ as was heavy lifting and shift work in Swedish laboratory workers. ${ }^{21}$ The adverse experience of women in the present study whose job entailed heavy lifting, physical effort, long hours, changing shift, or standing supports the hypothesis that phys- ical stress of this sort may have been causal. The alternative explanation of bias was probably excluded by the grouped analysis; the risk was related to level of exposure and the association with each factor was independent of the others. Moreover, such hypotheses appear biologically plausible.

Physical, chemical, and biological exposures were investigated in a large study of abortion in Finland in which occupational titles were linked to hospital admission records. ${ }^{22}$ For seven major exposure cate-

Table 8 Ratios of observed $(O)$ to expected $(E)$ abortions and stillbirths by chemical exposure and occupational sector

\begin{tabular}{|c|c|c|c|c|c|c|c|c|c|c|c|}
\hline \multirow{2}{*}{\multicolumn{2}{|c|}{$\begin{array}{l}\text { Chemical } \\
\text { exposure }\end{array}$}} & \multicolumn{2}{|c|}{ Managerial } & \multicolumn{2}{|c|}{$\stackrel{2}{\text { Health }}$} & \multicolumn{2}{|c|}{$\begin{array}{l}5 \\
\text { Services }\end{array}$} & \multicolumn{2}{|c|}{$\begin{array}{l}6 \\
\text { Manufacturing }\end{array}$} & \multicolumn{2}{|l|}{ All } \\
\hline & & $O$ & $O / E$ & $O$ & $O / E$ & $O$ & $O / E$ & $O$ & $O / E$ & $O$ & $O / E$ \\
\hline $\begin{array}{l}\text { Solvents: } \\
\text { All } \\
\text { Alone }\end{array}$ & $\begin{array}{l}\text { Abortion } \\
\text { Stillbirth } \\
\text { Abortion } \\
\text { Stillbirth }\end{array}$ & $\begin{array}{r}27 \\
0 \\
3 \\
0\end{array}$ & $\begin{array}{l}0.63 \\
\frac{0.28}{-}\end{array}$ & $\begin{array}{r}44 \\
2 \\
35 \\
2\end{array}$ & $\begin{array}{l}0.97 \\
1.10 \\
1.00 \\
1.44\end{array}$ & $\begin{array}{l}8 \\
0 \\
8 \\
0\end{array}$ & $\frac{0.82}{0.84}$ & $\begin{array}{r}140 \\
13 \\
119 \\
11\end{array}$ & $\begin{array}{l}1 \cdot 22^{* * *} \\
2 \cdot 76^{* * *} \\
1 \cdot 18^{* *} \\
2 \cdot 63^{* * *}\end{array}$ & $\begin{array}{r}219 \\
15 \\
165 \\
13\end{array}$ & $\begin{array}{l}1.03 \\
1.72^{* *} \\
1.06 \\
2.01^{* * *}\end{array}$ \\
\hline $\begin{array}{l}\text { Pesticides } \\
\text { All } \\
\text { Alone }\end{array}$ & $\begin{array}{l}\text { s† } \\
\text { Abortion } \\
\text { Stillbirth } \\
\text { Abortion } \\
\text { Stillbirth }\end{array}$ & $\begin{array}{l}0 \\
0 \\
0 \\
0\end{array}$ & $\begin{array}{l}E \\
-\end{array}$ & $\begin{array}{r}39 \\
0 \\
16 \\
0\end{array}$ & $\begin{array}{l}0.97 \\
\frac{0.98}{-}\end{array}$ & $\begin{array}{l}6 \\
0 \\
6 \\
0\end{array}$ & $\frac{1.20}{1.20}$ & $\begin{array}{l}0 \\
0 \\
0 \\
0\end{array}$ & $\begin{array}{l}- \\
-\end{array}$ & $\begin{array}{r}45 \\
2 \\
22 \\
0\end{array}$ & $\begin{array}{l}0.99 \\
1.11 \\
1.03 \\
-\end{array}$ \\
\hline $\begin{array}{l}\text { Anaesthe } \\
\text { All } \\
\text { Alone }\end{array}$ & $\begin{array}{l}\text { tic gases: } \\
\text { Abortions } \\
\text { Stillbirth } \\
\text { Abortion } \\
\text { Stillbirth }\end{array}$ & $\begin{array}{l}0 \\
0 \\
0 \\
0\end{array}$ & $\begin{array}{l}E \\
z\end{array}$ & $\begin{array}{r}17 \\
1 \\
1 \\
0\end{array}$ & $\begin{array}{l}1.07 \\
1.71 \\
1.40 \\
-\end{array}$ & $\begin{array}{l}0 \\
0 \\
0 \\
0\end{array}$ & $\begin{array}{l}- \\
-\end{array}$ & $\begin{array}{l}0 \\
0 \\
0 \\
0\end{array}$ & $\begin{array}{l}E \\
z\end{array}$ & $\begin{array}{r}17 \\
1 \\
1 \\
0\end{array}$ & $\begin{array}{l}1.07 \\
1.71 \\
1.40 \\
-\end{array}$ \\
\hline $\begin{array}{l}\text { Other che } \\
\text { All } \\
\text { Alone }\end{array}$ & $\begin{array}{l}\text { emicals: } \\
\text { Abortion } \\
\text { Stillbirth } \\
\text { Abortion } \\
\text { Stillbirth }\end{array}$ & $\begin{array}{r}24 \\
10 \\
0 \\
29\end{array}$ & $\begin{array}{l}0.72 \\
- \\
-\end{array}$ & $\begin{array}{r}29 \\
1 \\
21 \\
0\end{array}$ & $\begin{array}{l}1 \cdot 20 \\
0 \cdot 95 \\
1 \cdot 27 \\
-\end{array}$ & $\begin{array}{r}106 \\
3 \\
106 \\
3\end{array}$ & $\begin{array}{l}1.04 \\
0 \cdot 70 \\
1.04 \\
0.70\end{array}$ & $\begin{array}{r}79 \\
5 \\
58 \\
3\end{array}$ & $\begin{array}{l}1 \cdot 19 \\
1 \cdot 72 \\
1 \cdot 11 \\
1 \cdot 26\end{array}$ & $\begin{array}{r}238 \\
9 \\
185 \\
6\end{array}$ & $\begin{array}{l}1.05 \\
0.93 \\
1.08 \\
0.80\end{array}$ \\
\hline
\end{tabular}

${ }^{*} \mathrm{p}<0.1 ; * * \mathrm{p}<0.05 ; * * * \mathrm{p}<0.01$.

tIncluding bactericides, fungicides, and herbicides. 
gories, one of which was organic solvents, no increase in risk of abortion was found. Our findings on abortion were similar when all sectors were taken together, although increased $\mathrm{O} / \mathrm{E}$ ratios were clearly present in the manufacturing sector for both abortion and stillbirth (table 8). Laboratory technicians have been reported at increased risk, ${ }^{1922-24}$ but two studies in which response bias was eliminated or reduced gave negative results. ${ }^{2125}$ In our study the findings for hospital laboratory workers and for physical and life scientist groups (which included other laboratory technicians) were also negative.

In the present study operating room nurses had an excess of late abortions but not of abortions at less than 16 weeks. A report from the USSR in 1967 pointed to work in operating rooms as a possible cause of general health complaints and spontaneous abortion. ${ }^{2627}$ Later studies in which postal questionnaires were used gave positive findings, including one which was very large. ${ }^{28}$ In one such questionnaire study response was detected by checking reported abortions against those registered in hospital. When allowance was made for this bias the result was negative. ${ }^{29}$ In two recent investigations of nurses using recorded information on employment and hospital admission no association with spontaneous abortion was found. ${ }^{30} 31$

Despite the possibility of recall bias in questions about use of antineoplastic drugs, we found no evidence of an association with abortion in past pregnancies $(\mathrm{O} / \mathrm{E}=0.97)$ or current pregnancies $(\mathrm{O} / \mathrm{E}=0.96)$; the combined $\mathrm{O} / \mathrm{E}$ ratio was $0.95(95 \%$ CI $0.56-1.50$ ). Only 137 women were at risk and we had no quantitative information on exposure-even on the use of gloves and hoods. Nevertheless, our findings do not support the reported association between administration of cytostatic drugs and abortion $^{32}$ in which an odds ratio of $2.30(95 \%$ CI $1 \cdot 20-4 \cdot 39)$ was found.

Following a reported association between leather work, stillbirth, and a rare congenital defect (trisomy 18), ${ }^{11}$ preliminary analysis of our data confirmed the relation with stillbirth but not with congenital defect. ${ }^{12}$ In the present more comprehensive analyses an increased risk of stillbirth was found both in leatherworkers and in other manufacturing industries. There was also a small increase in the risk of abortion in the manufacturing sector in occupations in which solvent exposure occurred. These findings are supported by a study in Denmark of female workers exposed to chemicals identified from employer and union lists. Their reproductive experience was compared with that of workers similar in socioeconomic status and physical demands but with little exposure to chemicals. ${ }^{53}$ Three occupational groups, laboratory workers, dental assistants, and gardening work- ers, had no increase in abortion risk by contrast with factory workers and painters exposed to solvents. Our observation of increased $\mathrm{O} / \mathrm{E}$ ratios for late abortions and stillbirths in operating room nurses, radiology technicians, and agricultural and horticultural workers suggests the possibility of some fetotoxic agent or agents in these occupations. Further study of these groups is clearly warranted.

We acknowledge the invaluable cooperation of staff members in the 11 hospital maternity units (Charles Lemoyne, Jewish General, Laval, MaisonneuveRosemont, Notre-Dame, Sacré-Coeur, Ste-Justine, St-Luc, Royal Victoria, Ste-Mary's, St-Michel); we thank our nurses and clerks for their hard work and Drs C Commandeur, S Marquis, and I Tsarevsky for their many contributions.

\section{References}

1 McDonald AD, McDonald JC, Nolin AD, et al. Occupation and pregnancy outcome. Br J Ind Med 1987;44:521-6.

2 McDonald AD, Armstrong B, Cherry NM, et al. Spontaneous abortion and occupation. J Occup Med 1986;28:1232-8.

3 Standard occupational classification. Ottawa: Statistics Canada, 1980.

4 Standard industrial classification. Ottawa: Statistics Canada, 1980.

5 McDonald AD, Cherry NM, Delorme C, McDonald JC. Visual display units and pregnancy: evidence from the Montreal survey. J Occup Med 1986;28:1226-31.

$6 \mathrm{McDonald}$ AD. Work and pregnancy in Montreal. Presented at 2nd international conference on Allegations of Reproductive Hazards from VDUs, London 1986. London: Humane Technology, 1986.

7 McDonald JC, Lavoie J, Côté R, McDonald AD. Chemical exposures at work in early pregnancy and congenital defect: a case-referent study. Br J Ind Med 1987;44:527-33.

8 Gérin M, Siemiatycki J, Kemper H, Bégin D. Obtaining occupational exposure histories in epidemiologic case-control studies. J Occup Med 1985;27:420-6.

9 Baker RJ, Nelder JA. The GLIM system: release 3. Oxford: Numerical Algorithms Group, 1978.

10 Morgenstern $H$. Uses of ecologic analysis in epidemiological research. Am J Public Health 1982;72:1336-44.

11 Clarke MC, Mason ES. Leatherwork: a possible hazard to reproduction. Br Med J 1985;290:1235-7.

12 McDonald AD, McDonald JC. Outcome of pregnancy in leatherworkers. Br Med J 1986;292:979-81.

13 Leridon H. Facts and artifacts in the study of intra uterine mortality: a reconsideration from pregnancy histories. Population Studies (London) 1976;30:319-35.

14 Niemi ML, Hemminki K, Sallunén M. Applications of hospital discharge register for studies on spontaneous abortions. In: Hemminki K, Sorsa M, Vainio H, eds. Occupational hazards and reproduction. Washington: Hemisphere Publishing Co, 1985.

15 Wilcox AJ, Horney LF. Accuracy of spontaneous abortion recall. Am J Epidemiol 1984;120:727-33.

16 Hemminki K, Niemi ML, Saloniemi I, Vainio H, Hemminki E. Spontaneous abortions by occupation and social class in Finland. Int J Epidemiol 1980;9:149-53.

17 Shilling S, Lalich NR. Maternal occupation and industry and the 
pregnancy outcome of US married women, 1980. Public Health Rep 1984;99:152-61.

18 Hemminki K, Niemi ML, Koskinen K, Vainio H. Spontaneous abortions among women employed in the metal industry in Finland. Int Arch Occup Environ Health 1980;47:53-60.

19 Vaughan TL, Daling JR, Starzyk PM. Fetal death and maternal occupation. An analysis of birth records in the State of Washington. J Occup Med 1984;26:676-8.

20 Taskinen H, Lindbohm ML, Hemminki K. Spontaneous abortions among women working in the pharmaceutical industry. Br J Ind Med 1986;43:199-205.

21 Axelsson G. Lutz C, Rylander R. Exposure to solvents and outcome of pregnancy in university laboratory employees. Br J Ind Med 1984;41:305-12.

22 Lindbohm ML, Hemminki K, Kyyronen P. Parental occupational exposure and spontaneous abortions in Finland. Am J Epidemiol 1984;120:370-8.

23 Strandberg M, Sandback K, Axelson O, Sundell L. Spontaneous abortions among women in hospital laboratory. Lancet 1978;i:384-5.

24 Hansson E, Jansa S, Wande H, Kallén B, Ostlund E. Pregnancy outcome for women working in laboratories in some of the pharmaceutical industries in Sweden. Scand $J$ Work Environ Health 1980;6:131-4.

25 Heidam LZ. Spontaneous abortions among laboratory workers a follow up study $J$ Epidemiol Community Health
1984;38:36-41.

26 Vaisman AL. Working conditions in surgery and their effect on the health of anaesthesiologists. Eksperimentalnaia Khirurgiia Anesteziologiia 1967;3:44-8.

27 Ferstandig LL. Trace concentrations of anesthetic gases. Acta Anaesth Scand 1982;75:38-43.

28 Cohen EN, Belleville JW, Brown BW, et al. Occupational disease among operating room personnel: a national study. Anesthesiology 1974;41:321-40.

29 Axelsson G, Rylander R. Exposure to anaesthetic gases and spontaneous abortion: response bias in a postal questionnaire study. Int J Epidemiol 1982;11:250-6.

30 Ericson HA, Kallén AJ. Hospitalization for miscarriage and delivery outcome among Swedish nurses working in operating rooms 1973-1978. Anesth Analg 1985;64:981-8.

31 Hemminki K, Kyyronen P, Lindbohm ML. Spontaneous abortions and malformations in the offspring of nurses exposed to anaesthetic gases, cytostatic drugs, and other potential hazards in hospitals, based on registered information of outcome. $J$ Epidemiol Community Health 1985;39:141-7.

32 Selevan SG, Lindbohm ML, Hornung RW, Hemminki K. A study of occupational exposure to antineoplastic drugs and fetal loss in nurses. $N$ Engl J Med 1985;313:1173-8.

33 Heidam LZ. Spontaneous abortions among dental assistants, factory workers, painters, and gardening workers: a follow up study. J Epidemiol Community Health 1984;38:149-55.

\section{Correspondence and editorials}

The British Journal of Industrial Medicine welcomes correspondence relating to any of the material appearing in the journal. Results from preliminary or small scale studies may also be published in the correspondence column if this seems appropriate. Letters should be not more than 500 words in length and contain a minimum of references. Tables and figures should be kept to an absolute minimum. Letters are accepted on the understanding that they may be subject to editorial revision and shortening.

The journal now also publishes editorials which are normally specially commissioned. The Editor welcomes suggestions regarding suitable topics; those wishing to submit an editorial, however, should do so only after discussion with the Editor. 